\title{
Optimization of reed-specific degrading bacteria by re- sponse surfaces for remediation of crude oil-polluted soil in Xinjiang, China
}

\author{
YaMing DONG ${ }^{1,2^{*}}$, ChaoCheng ZHAO ${ }^{1}$, Yun $\mathrm{CAI}^{1}$, DongFeng ZHAO ${ }^{1}$ \\ ${ }^{1}$ College of Chemistry and Chemical Engineering, China University of Petroleum, Qingdao 266555, China; \\ ${ }^{2}$ Xinjiang Department of Environmental Protection, Urumqi 830000, China
}

\begin{abstract}
This paper discussed the optimization of conditions for remediation of crude oil-polluted soil based on pot experiment by applying reed-specific degrading bacteria, and using response surfaces methodology. We took the initial crude oil concentration, the amount of inoculation, the ratio of nitrogen and phosphorus, and the use of surfactant (Tween-80) as independent variables (factors), and the degrading ratio of crude oil as the dependent variable (response) after a 90-day experiment. The experiment explored the impacts of each independent variable and their interactions on the bioremediation of crude oil-polluted soil using the Box-Behnken design. Working with a simulated forecasting model the study obtained optimization values for the treatment parameters of $200 \mathrm{~g} / \mathrm{kg}$ of the reed+specific degrading bacteria, a nitrogen to phosphorus ratio of about 6.0 , and $0.2 \%$ surfactant. Under experimental conditions, for crude oil concentrations of 10,30 and $50 \mathrm{~g} / \mathrm{kg}$, the optimal effects of the treatments achieved $71.87 \%, 66.61 \%$ and $54.52 \%$ degradation of the crude oil, respectively. The results can provide a basis for the technical development of plant-microorganism combined bioremediation of crude oil-polluted soil.
\end{abstract}

Keywords: crude oil pollution; plant-microorganism; response surfaces; soil remediation

Citation: YaMing DONG, ChaoCheng ZHAO, Yun CAI, DongFeng ZHAO. 2013. Optimization of reed-specific degrading bacteria by response surfaces for remediation of crude oil-polluted soil in Xinjiang, China. Journal of Arid Land, 5(3): 408-414.

Xinjiang is an important oil producing region, yielding 1/8 of China's crude oil output (Yang, 2003). In the processes of crude oil exploration, storage and transportation, refining and machining, soil has suffered from serious oil pollution, resulting in huge economic losses (Guo, 2000; Sun and Yu, 2002). So, the remediation of crude oil-polluted soil has become an urgent issue to address. The search for remedial methods is at the core of the development of remediating technology.

Compared to physical and chemical remediation, bioremediation has less impact on human beings and the environment, and its cost is only $30 \%-50 \%$ of traditional physical and chemical remediation methods; it can be a highly efficient, economical and environ- mentally-friendly clean technology (Qian and Liu, 2000; Liu et al., 2006; Cheng and Li, 2007; Mallavarapu et al., 2011). At present, bioremediation is mainly used for pollution control in soil, groundwater and oceans, and is in situ remediation (Rizzo et al., 2008; Beskoski et al., 2012). Plant-microorganism combined bioremediation is a valuable research direction, providing a synergistic effect between plants and special mycorrhizal fungi or rhizosphere microbes to increase the absorption and degradation of pollutants (Okoh and Trejo-Hernandez, 2006; Mohsenzadeh et al., 2010; Du et al., 2011; Liu et al., 2011). Zhang et al. (2009) and Chen et al. (2010), compared the effects of plant, microorganism and plant-microorganism combined remediation, respectively, and found that the

*Corresponding author: YaMing DONG (E-mail: doym@163.com) Received 2012-10-18; revised 2013-02-23; accepted 2013-03-04

(C) Xinjiang Institute of Ecology and Geography, Chinese Academy of Sciences, Science Press and Springer-Verlag Berlin Heidelberg 2013 
impact of plant-microorganism combined remediation had the biggest beneficial effect. In pot experiments with ryegrass (Lolium perenne) and microorganisms, Tang et al. $(2009,2010)$ found that soil remediation by the combination of ryegrass and mixed microbial strains gave the best result, with a degradation rate of $58 \%$ after a 162-day treatment, which was significantly higher than that of the control. The experiment of Liu et al. (2009) showed that after a 120-day treatment, the degradation rate of petroleum in soil in treatment with adding microorganisms was $67.0 \%$; the degrees of degradation were $38.23 \%, 36.57 \%, 40.67 \%$ and $38.67 \%$, respectively, planted with sunflower, cotton, Bermuda grass, and Sudan grass; and the degree of petroleum degradation reached as high as $85.67 \%$ with cotton+microorganisms treatment. In a 2-year experiment to evaluate the remediation effect of plant-microorganism combinations on diesel-polluted soil, Lin et al. (2008) found that the removal rate of diesel oil using combined plant-microorganism was over $67 \%$, which was $13 \%-30 \%$ higher than that achieved by plants alone. These results showed that an appropriate plant-microorganism synergy provides an approach of low cost, highly efficient remediation for oil-polluted soil.

By choosing appropriate combinations of plants and microbes, polluted soil can be remediated. However, to obtain the expected result, the relationship between pollutants, plant species/variety and microorganism needs in-depth understanding, so that the remediation process can be effectively controlled. At present, the research in this field in China is mainly focused on microbial remediation, and there is less research on plant remediation and plant-microorganism combined remediation. In particular, the mechanisms and control factors for plant-microorganism combined remediation systems still lack in-depth understanding. Our study, based on the climate characteristics of Xinjiang, previous experiments and relevant information (Morgan and Watkinson, 1994; Sun and Song, 1999; Xia and Lin, 2000; Ren et al., 2004), found that reeds had a favorable effect on the remediation of crude oil-polluted soil, and that screened, mixed KL8-1 bacteria from the reed rhizosphere were effective in degrading oil. By pot experiment, the study optimized the amount of inoculation, surfactant, nitrogen and phosphorus nutrients and soil water-retaining agent by using a response surfaces method to study the effect of reed-specific degrading bacteria remediation on crude oil-polluted soil. The aims were to research a rapid method for using reed-specific bacteria for degrading hydrocarbon pollutants of petroleum, and to provide support for establishing the technology of plant-microorganism combined remediation for crude oil-polluted soil of Xinjiang.

\section{Materials and methods}

\subsection{Experimental design}

The soil samples for the experiment were taken from the top $20 \mathrm{~cm}$ of unpolluted soil in the Karamy region. The mechanical composition of this soil is $18.2 \%$ sand, $58.4 \%$ silt and $23.4 \%$ clay. The soil samples were first sieved with a $2-\mathrm{mm}$ mesh to remove large particles. The specific degrading bacteria KL8-1 used in the experiment were raised in the laboratory. One kilogram of soil was put into each of 35 cylindrical pots with the diameter of $10 \mathrm{~cm}$ and the height of $15 \mathrm{~cm}$. The crude oil came from Karamy's second oil refinery. After $24 \mathrm{~h}$ of the soil mixing with the crude oil, nitrogen and phosphorus nutrient salts (using ammonium chloride and potassium phosphate) were added to the soil in the pots. The experiment contained 35 samples, of which 6 samples were controls. The samples 30-32 were controls with reed and samples 33-35 were controls without reed. The mixed bacteria KL8-1 were placed in pots of polluted soil, and then $20-\mathrm{cm}$ reed seedlings were planted in the soil. During the experimental process, water was periodically irrigated to maintain the soil water content at around $20 \%$. After 90 days the oil content in the soils was determined. The above steps were repeated 3 times using different amounts of the variables (crude oil, N:P ratios, KL8-1 bacteria and surfactant) (Table 1).

\subsection{Measuring methods}

The content of petroleum hydrocarbons in soil samples was determined by placing $2 \mathrm{~g}$ of dried soil into a $50-\mathrm{mL}$ centrifugal tubes, adding $10-\mathrm{mL}$ acetone/dichloromethane $(1: 1)$, conducting ultrasonic extraction for $15 \mathrm{~min}$ (minimum $300 \mathrm{~W}$ ) and then centrifuging the samples at 7,500 rev./min for $10 \mathrm{~min}$. The result- 
ing upper clear liquid was collected and filtrated by anhydrous sodium sulfate (dried for $2 \mathrm{~h}$ at $300^{\circ} \mathrm{C}$ ). The crude oil contents in the pots were determined by spectrophotometry and using an infrared oil-measuring instrument (Model 510, ChinaInvent Instruments, China) (Morgan and Watkinson, 1994; Sun and Song, 1999; Qian and Liu, 2000; Ren et al., 2004).

\subsection{Analysis method}

Using the Box-Behnken method (Ferreira et al., 2007), the optimum balance of the 4 factors (different concentrations of crude oil-pollution, different inoculations of specific degrading bacteria, varied ratios of nitrogen and phosphorus, and different amounts of surfactant) was established for the effect of the combined remediation of reed-specific degrading bacteria on crude oil-polluted soil (Tables 1 and 2). The results

Table 1 Code and actual values of variables used in the response surfaces

\begin{tabular}{lcccc}
\hline Level & Code A & \multicolumn{2}{c}{ Code B Code C } & Code D \\
\cline { 2 - 5 } & $\begin{array}{c}\text { Crude oil con- } \\
\text { centration }(\mathrm{g} / \mathrm{kg})\end{array}$ & $\begin{array}{c}\text { Bio- } \\
\text { mass }^{*}\end{array}$ & $\begin{array}{c}\text { N/P } \\
(\mathrm{v} / \mathrm{v})\end{array}$ & $\begin{array}{c}\text { Surfactant } \\
(\text { Tween 80; \% })\end{array}$ \\
\hline Low level (-1) & 10 & 0 & 5 & 0.2 \\
Medium level ( 0 ) & 30 & 1 & 6 & 0.6 \\
High level (+1) & 50 & 2 & 7 & 1.0 \\
\hline
\end{tabular}

Note: ${ }^{*}$, the specific amounts of degrading bacteria (fixed by adding sterilized peat in which the quantity of microorganisms reached $10^{10}$ ) were $0 \mathrm{~g} / \mathrm{kg}$ (coded 0$), 100 \mathrm{~g} / \mathrm{kg}(\operatorname{coded} 1)$ and $200 \mathrm{~g} / \mathrm{kg}(\operatorname{coded} 2)$.

Table 2 Box-Behnken experiment design and results

\begin{tabular}{|c|c|c|c|c|c|c|}
\hline \multirow{2}{*}{ No. } & \multirow{2}{*}{ Crude oil concentration $(\mathrm{g} / \mathrm{kg})$} & \multirow{2}{*}{ Biomass* } & \multirow{2}{*}{$\mathrm{N} / \mathrm{P}(\mathrm{g} / \mathrm{g})$} & \multirow{2}{*}{ Surfactant (Tween $80, \%$ ) } & \multicolumn{2}{|c|}{ Degrading rate $(\%)$} \\
\hline & & & & & Measured value & Predicted value \\
\hline 1 & 30 & 0 & 6 & 1.0 & 51.15 & 51.69 \\
\hline 2 & 50 & 1 & 7 & 0.6 & 60.64 & 59.98 \\
\hline 3 & 30 & 0 & 6 & 0.2 & 45.57 & 46.96 \\
\hline 4 & 30 & 2 & 7 & 0.6 & 62.68 & 61.64 \\
\hline 5 & 50 & 1 & 5 & 0.6 & 52.16 & 54.11 \\
\hline 6 & 30 & 1 & 7 & 0.2 & 56.28 & 56.31 \\
\hline 7 & 30 & 2 & 5 & 0.6 & 63.76 & 62.17 \\
\hline 8 & 10 & 1 & 7 & 0.6 & 60.16 & 59.96 \\
\hline 9 & 30 & 1 & 5 & 0.2 & 57.32 & 56.10 \\
\hline 10 & 30 & 1 & 6 & 0.6 & 50.47 & 50.63 \\
\hline 11 & 30 & 2 & 6 & 0.2 & 65.36 & 66.67 \\
\hline 12 & 10 & 1 & 5 & 0.6 & 59.80 & 61.39 \\
\hline 13 & 30 & 0 & 7 & 0.6 & 43.19 & 43.63 \\
\hline 14 & 30 & 1 & 6 & 0.6 & 61.35 & 61.35 \\
\hline 15 & 30 & 1 & 6 & 0.6 & 61.35 & 61.35 \\
\hline 16 & 10 & 1 & 6 & 0.2 & 64.21 & 63.22 \\
\hline 17 & 50 & 1 & 6 & 1.0 & 56.29 & 56.13 \\
\hline 18 & 50 & 0 & 6 & 0.6 & 46.96 & 45.36 \\
\hline 19 & 10 & 0 & 6 & 0.6 & 53.41 & 52.72 \\
\hline 20 & 50 & 2 & 6 & 0.6 & 60.44 & 60.50 \\
\hline 21 & 30 & 0 & 5 & 0.6 & 48.11 & 48.00 \\
\hline 22 & 30 & 2 & 6 & 1.0 & 63.92 & 64.28 \\
\hline 23 & 30 & 1 & 6 & 0.6 & 61.35 & 61.35 \\
\hline 24 & 30 & 1 & 7 & 1.0 & 54.28 & 54.87 \\
\hline 26 & 30 & 1 & 6 & 0.6 & 56.08 & 55.63 \\
\hline 27 & 10 & 2 & 6 & 0.6 & 61.35 & 61.35 \\
\hline 28 & 10 & 1 & 6 & 1.0 & 68.78 & 69.75 \\
\hline 29 & 30 & 1 & 5 & 1.0 & 65.86 & 65.16 \\
\hline 30 & 10 & 0 & 0 & 0 & 12.50 & - \\
\hline 31 & 30 & 0 & 0 & 0 & 11.80 & - \\
\hline 32 & 50 & 0 & 0 & 0 & 10.30 & - \\
\hline 33 & 10 & 0 & 0 & 0 & 5.21 & - \\
\hline 34 & 30 & 0 & 0 & 0 & 4.36 & - \\
\hline 35 & 50 & 0 & 0 & 0 & 4.98 & - \\
\hline
\end{tabular}

Note: ${ }^{*}$, the specific amounts of degrading bacteria (fixed by adding sterilized peat in which the quantity of microorganisms reached $10^{10}$ ) were $0 \mathrm{~g} / \mathrm{kg}$ (coded 0), $100 \mathrm{~g} / \mathrm{kg}(\operatorname{coded} 1)$ and $200 \mathrm{~g} / \mathrm{kg}(\operatorname{coded} 2)$. 
were fitted using quadratic multinomial regression. This was applied to predict the optimal point using differential calculations. SPSS statistical software was employed to conduct significance tests for the fitting equation and variance analysis. In the experimental process the crude oil concentration in the soil was $10-50 \mathrm{~g} / \mathrm{kg}$, the nitrogen content was between $0.2-3.0$ $\mathrm{g} / \mathrm{kg}$, and the specific amounts of degrading bacteria (fixed by adding sterilized peat in which the quantity of microorganisms reached $10^{10}$ ) were $0 \mathrm{~g} / \mathrm{kg}$ (coded $0), 100 \mathrm{~g} / \mathrm{kg}$ (coded 1) and $200 \mathrm{~g} / \mathrm{kg}(\operatorname{coded} 2)$.

\section{Results and discussion}

\subsection{Results of remediation to crude oil-polluted soil using reed-specific degrading bacteria}

After 60 days of plant-microorganism combined remediation, the crude oil contents in every treatment were reduced (Table 2). Because of the natural volatilization and light oxidation action, the rates of crude oil degradation in control pots were $10.3 \%-12.5 \%$. The crude oil degradation in the soils with reed-specific degrading bacteria was significantly better than that of the control soils, recording crude oil degradation up to $43.19 \%-68.18 \%$. In the soils with crude oil concentrations of 10,30 and $50 \mathrm{~g} / \mathrm{kg}$, the degradation rates of petroleum hydrocarbons reached $68.78 \%, 65.86 \%$ and $60.64 \%$, respectively, which indicated that crude oil concentration had a great impact on remediation by reed-specific degrading bacteria. Lower oil concentration allowed the reed-specific degrading bacteria to be more effective. The amount of surfactant had no remarkable impact on reed-specific degrading bacteria. This may be related to the fact that the specific degrading bacteria KL8-1 contains the surfactant which produces bacteria Bacillus subtilis. Reed-specific degrading bacteria were most effective at the nitrogen and phosphorus ratio of 6 and KL8-1 concentration of $200 \mathrm{~g} / \mathrm{kg}$.

\subsection{Establishment of fitting model for reed-speci- fic degrading bacteria remediation}

Using the Box-Behnken design method, the 4 factors (the concentrations of crude oil, the amount of inoculation, the ratio of nitrogen and phosphorus, and the amount of surfactant added) optimized the effect of combined remediation of reed-specific degrading bacteria on crude oil-polluted soil. A prediction model of the quadratic multinomial regression equation is as follows:

$$
\begin{aligned}
Y= & 61.35-4.15 A+8.05 B-1.23 C+0.61 D-0.47 A B- \\
& 0.51 A C-0.36 A D+0.96 B C-1.75 B D- \\
& 1.33 C D-0.80 A^{2}-3.46 B^{2}-4.02 C^{2}-0.51 D^{2} .
\end{aligned}
$$

Where, $\mathrm{Y}$ is the predicted petroleum degrading rate; $\mathrm{A}, \mathrm{B}$, $\mathrm{C}$ and $\mathrm{D}$ represent the concentrations of crude oil, the amount of inoculation, the ratio of nitrogen and phosphorus, and the amount of surfactant added (Tween-80), respectively.

The variance analysis of the prediction model showed that the experimental results were consistent with the prediction model of the quadratic multinomial regression equation, with $R^{2}=0.9819$ (Table 3). The equation can well predict the effect of remediating crude oil-polluted soil using reed-specific degrading bacteria. In addition, the results show that the 4 factors $\mathrm{A}, \mathrm{B}, \mathrm{B}^{2}$ and $\mathrm{C}^{2}$ had significant impact on the effect of combining plant-microorganism remediation.

The response surfaces of the different factors which impacted the remediation of crude oil-polluted soil using reed-specific degrading bacteria and their interaction (Fig. 1a) show that the higher the amount of microbial inoculation, the more the reducing crude oil concentration, and the better is the remediation effect. This indicates that microorganisms for degrading crude oil are one of the key factors in the biological remediation process. In addition, while crude oil concentration is low, the ratio of toxic substance to microorganisms is low and the degradation by the microorganisms is effective. When crude oil concentration increases, the concentration of toxic and harmful substances in the crude oil will increase, and then the effectiveness of bioremediation declines. The study of Zhu et al. (2001) found the same results.

The addition of nitrogen-phosphorus nutrient salts and surfactant can accelerate crude oil degradation. The actions of nutrient salts are mainly to promote microbial development and reproduction which benefits the process of degradation (Walworth et al., 2001). The study of $\mathrm{He}$ et al. (2004) found that excessive nitrogen inhibited crude oil degradation, and it is more suitable that the ratio of nitrogen and phosphorus is 
Table 3 Variance analysis for prediction model of response surfaces' quadratic multinomial

\begin{tabular}{ccrrcc}
\hline & The degree of freedom & Standard deviation & $F$ value & Prob $>F$ & The degree of significance \\
\hline Prediction function & 14 & 84.97 & 54.13 & $<0.0001$ & Significant \\
A & 1 & 206.84 & 131.76 & $<0.0001$ & Significant \\
B & 1 & 776.83 & 494.87 & $<0.0001$ & Significant \\
C & 1 & 18.08 & 11.52 & 0.0044 & Non-significant \\
D & 1 & 4.47 & 2.84 & 0.1138 & Non-significant \\
AB & 1 & 0.89 & 0.57 & 0.4632 & Non-significant \\
AC & 1 & 1.05 & 0.67 & 0.4270 & Non-significant \\
AD & 1 & 0.52 & 0.33 & 0.5746 & Non-significant \\
BC & 1 & 3.69 & 2.35 & 0.1477 & Non-significant \\
BD & 1 & 12.32 & 7.85 & 0.0141 & Non-significant \\
CD & 1 & 7.08 & 4.51 & 0.0521 & Non-significant \\
$\mathrm{A}^{2}$ & 1 & 4.16 & 2.65 & 0.1258 & Non-significant \\
$\mathrm{B}^{2}$ & 1 & 77.75 & 49.53 & $<0.0001$ & Significant \\
$\mathrm{C}^{2}$ & 1 & 104.93 & 66.85 & $<0.0001$ & Significant \\
$\mathrm{D}^{2}$ & 1 & 1.68 & 1.07 & 0.3190 & Non-significant \\
$R^{2}=0.9819$ & 14 & 1.57 & & & \\
\hline
\end{tabular}

Note: A, B, C and D represent the concentrations of crude oil, the amount of inoculation, the ratio of nitrogen and phosphorus, and the amount of surfactant added (Tween-80), respectively.

- Design points above predicted value

- Design points below predicted value
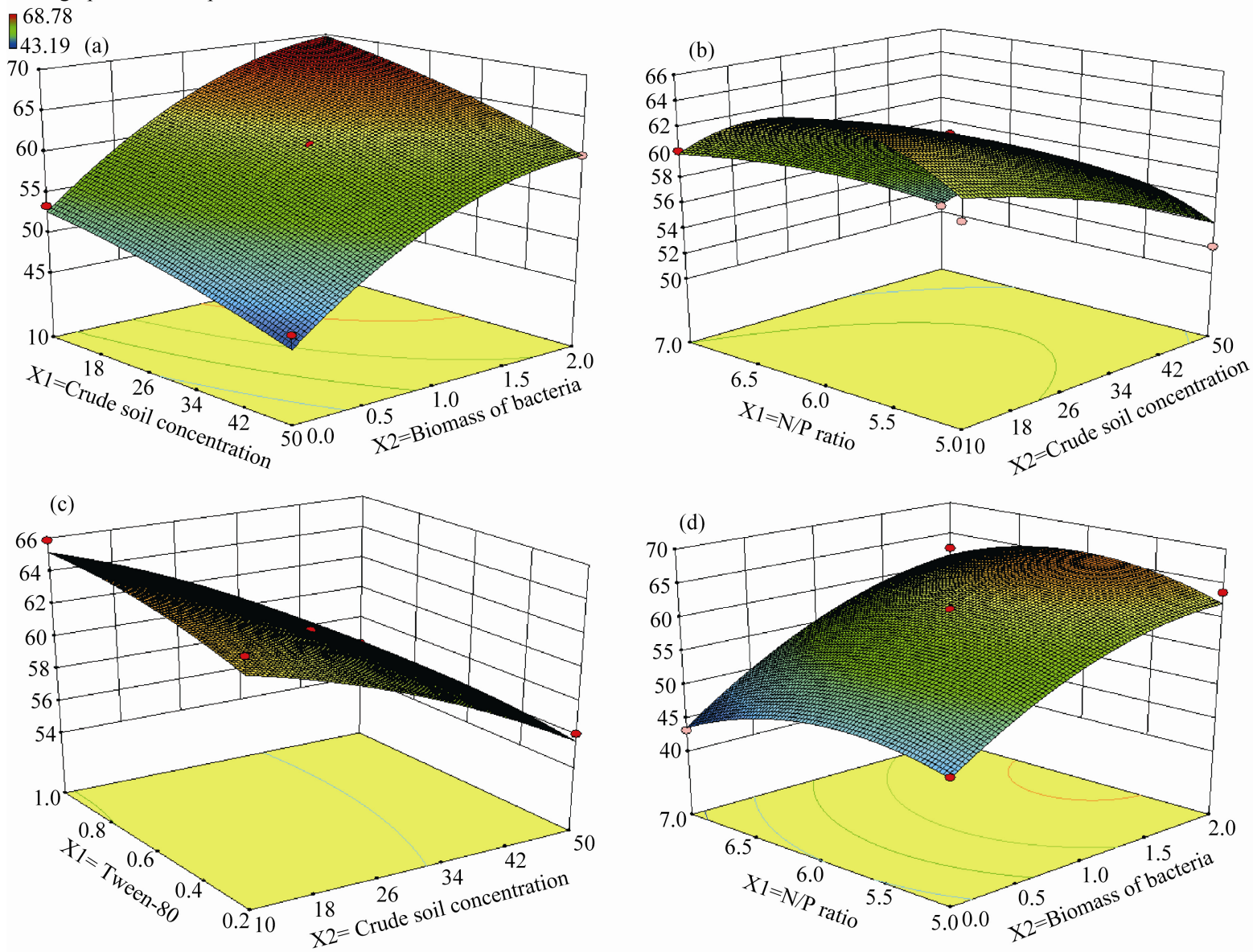

Fig. 1 Response surfaces of impacts of different factors and their interaction. (a) crude oil concentration and biomass of bacteria; (b) crude oil concentration and N/P ratio; (c) crude oil concentration and surfactant; (d) N/P ratio and biomass of bacteria. 
between 5:1 and 6:1. From Fig. $1 \mathrm{~b}$ it can be seen that when the ratio of nitrogen and phosphorus is 6 , the degradation is the most complete. The effect on crude oil degradation through adding nutrient salts into reed-specific degrading bacteria was better than that of reed-specific degrading bacteria. This may be because the nutrient salts promote the coordinated action between reed and specific degrading bacteria KL8-1. The effect of adding surfactant into the reed-specific degrading bacteria was not significant to the degradation effect of crude oil. When the surfactant concentration was increased, the rate of crude oil degradation showed almost no change (Fig. 1c). From the response surfaces of nutrient salts (the ratio of nitrogen and phosphorus) and their interaction (Fig. 1d), it can be seen that when the ratio of nitrogen and phosphorus is 6 and the biomass of bacteria is the largest, the effect on hydrocarbon degradation is the best. However, adding extra nitrogen (the ratio of nitrogen to phosphorus was 7) did not improve the effect of crude oil degradation.

\subsection{Validation of prediction model}

Under different conditions of crude oil concentration, the validation to the optimized results of the prediction model showed that under the optimum condition, when crude oil concentrations were 10,30 and $50 \mathrm{~g} / \mathrm{kg}$, the effects of crude oil remediation were $71.87 \%$, $66.61 \%$ and $54.52 \%$ degradation, respectively, which is very near to the predicted values with the standard deviation of less than $2 \%$. This indicates that the prediction model can be used to predict the effect of reed-specific degrading bacteria remediation on crude oil-polluted soil. When crude oil concentrations were $50 \mathrm{~g} / \mathrm{kg}$, the removing rate of crude oil decreased to $53.52 \%$ (Table 4). Crude oil in high concentrations can restrain the growth of reeds and specific degrading bacteria, resulting in the drop in the removal rate of crude oil.

\section{Conclusions}

Using the Box-Behnken design, taking the initial crude oil concentration, the amount of inoculation, the ratio of nitrogen and phosphorus, and surfactant (Tween-80) as independent variables (factors), and taking the degrading ratio of crude oil after a 90-day experiment as a dependent variable (response), we studied the impacts of each independent variable and their interactions on the bioremediation of crude oilpolluted soil. The results show that the concentration of crude oil, the amount of microbial inoculation, and nutrient salts (the ratio of nitrogen and phosphorus) are the key factors affecting plant-specific degrading bacteria remediation in crude oil-polluted soil, and the best biological remediation conditions occurred with immobilized specific degrading bacteria of $200 \mathrm{~g} / \mathrm{kg}$, $\mathrm{N} / \mathrm{P}$ ratio of about 6 , and surfactant dosage of $0.2 \%$.

Taking the degradation rate of petroleum as the response value, the prediction model of the quadratic multinomial was obtained by conducting a simulation using the central combination of response surfaces. On the basis of the quadratic multinomial regression equation, the study calculated the optimal remediation effects on crude oil-polluted soil with crude oil contents of 10,30 and $50 \mathrm{~g} / \mathrm{kg}$, and generated crude oil degradation rates of $71.87 \%, 67.61 \%$ and $54.52 \%$, respectively. These are higher than the experimental values of $68.78 \%, 65.86 \%$ and $60.64 \%$ for each single factor. The response surfaces method is an effective approach for optimizing combinations of treatments for bioremediation of crude oil-polluted soil.

Table 4 Validation of model optimization for crude oil-polluted bioremediation

\begin{tabular}{|c|c|c|c|c|c|c|}
\hline \multirow{2}{*}{$\begin{array}{l}\text { Crude oil concentra- } \\
\text { tion }(\mathrm{g} / \mathrm{kg})\end{array}$} & \multirow{2}{*}{ Biomass $^{*}$} & \multirow{2}{*}{$\mathrm{N} / \mathrm{P}(\mathrm{g} / \mathrm{g})$} & \multirow{2}{*}{ Surfactant (\%o) } & \multicolumn{2}{|c|}{ Degrading rate $(\%)$} & \multirow{2}{*}{ SD } \\
\hline & & & & Measured value & Predicted value & \\
\hline 10 & 2 & 6.19 & 0.21 & 71.87 & 71.12 & 0.33 \\
\hline 30 & 2 & 6.11 & 0.22 & 66.61 & 67.39 & 1.56 \\
\hline 50 & 2 & 6.07 & 0.20 & 54.52 & 54.57 & 0.12 \\
\hline
\end{tabular}

Note: ${ }^{2}$, the specific amount of degrading bacteria (fixed by adding sterilized peat in which the quantity of microorganisms reached $10^{10}$ ) was $200 \mathrm{~g} / \mathrm{kg}$ (coded 2); $\mathrm{SD}=$ standard deviation. 


\section{Acknowledgements}

This research was supported by the Specialized Research Fund for the Basic Scientific Research of Higher Education of China (27R1204018A).

\section{References}

Beskoski V P, Gojgic-Cvijovic G D, Milic J S. 2012. Bioremediation of soil polluted with crude oil and its derivatives: microorganisms, degradation pathways, technologies. Hemijska Industrija, 66(2): 275-289.

Chen L, Zhang F W, Chen J. 2010. Study on plants-microbial in-situ remediation of petroleum contaminated soil. In: Conference on Environmental Pollution and Public Health (CEPPH 2010 E-BOOK). USA: Scientific Research Publishing, 598-602.

Cheng G L, Li P J. 2007. Petroleum contaminated soil phytoremediation and microbial remediation technology. Chinese Journal of Environmental Engineering, 6(1): 91- 94.

Du W D, Wan Y Y, Zhong N N. 2011. Status quo of soil petroleum contamination and evolution of bioremediation. Petroleum Science, 8(4): 502-514.

Ferreira S L C, Bruns R E, Ferreira H S, et al. 2007. Box-Behnken design: an alternative for the optimization of analytical methods. Analytica Chimica Acta, 597: 179-186.

Guo Z Q. 2000. The particularity of Xinjiang's crude oil and the significance in its exploration, development, and refining. Xinjiang Petroleum Geology, 21(5): 397-400.

He L J, Li P J, Wei D Z, et al. 2004. Nutrient balance and mechanism of biological degradation of oil. Environmentl Science, 25(1): 91-94.

Lin X, Li X J, Li P J. 2008. Evaluation of plant-microorganism synergy for the remediation of diesel fuel contaminated soil. Bulletin of Environmental Contamination and Toxicology, 81(1): 19-24.

Liu J C, Cui Y S, Zhang Y P. 2009. Effect of plants and microorganisms on remediation of petroleum contaminated soil. Journal of Ecology and Rural Environment, 25(2): 80-83.

Liu P W, Chang T C, Whang L M, et al. 2011. Bioremediation of petroleum hydrocarbon contaminated soil: effects of strategies and microbial community shift. International Biodeterioration \& Biodegradation, 65(8): 1119-1127.

Liu W X, Luo Y M, Teng Y, et al. 2006. Study on bioremediation of petroleum contaminated soils. Soil, 38(5): 634-639.

Mallavarapu M, Balasubramanian R, Kadiyala V, et al. 2011. Bioremediation approaches for organic pollutants: a critical perspective. Environment International, 37: 1362-1375.

Mohsenzadeh F, Nasseri S, Mesdaghinia A, et al. 2010. Phytoremedia- tion of petroleum-polluted soils: application of Polygonum aviculare and its root-associated (penetrated) fungal strains for bioremediation of petroleum-polluted soils. Ecotoxicology and Environmental Safety, 73(4): 613-619.

Morgan P, Watkinson R J. 1994. Biodegradation of components of petroleum. In: Ratledge C. Biochemistry of Microbial Degradation. Dordrecht: Kluwer Academic Publishers.

Okoh A I, Trejo-Hernandez M R. 2006. Remediation of petroleum hydrocarbon polluted systems: exploiting the bioremediation strategies. African Journal of Biotechnology, 5(25): 2520-2525.

Qian S Q, Liu Z. 2000. Introduction of soil remediation technology. Advances in Chemical Engineering, (4): 10-12.

Ren H F, Shan D C, Li S Q. 2004. Petroleum contaminated soil bioremediation technology research progress. Journal of Northeast Agricultural University, 35(3): 373-376.

Rizzo A C L, Santos R M, Sobral L G S. 2008. Bioremediation of Brazilian petroleum contaminated soil: auxiliary techniques evaluation in pilot scale. Remediation Concepts \& Technologies, 1(3): 1066-1075.

Sun Q F, Yu R F. 2002. Progress of petroleum contaminated soil treatment technology research. Metallic Ore Dressing Abroad, (12): 4-8.

Sun T H, Song Y F. 1999. Plant biological repair of PAHs and the regulation of mineral oil contaminated soil. Chinese Journal of Applied Ecology, 10(2): 225-229.

Tang J C, Niu X W, Sun Q. 2009. Bioremediation of petroleum polluted soil by combination of rye grass with effective microorganisms. International Conference on Environmental Science and Information Application Technology, II: 51-54.

Tang J C, Wang R G, Niu X W, et al. 2010. Enhancement of soil petroleum remediation by using a combination of ryegrass (Lolium perenne) and different microorganisms. Soil and Tillage Research, 110(1): 87-93.

Walworth J, Braddock J, Woolard C, et al. 2001. Nutrient and temperature interactions in bioremediation of cryic soils. Cold Regions Science and Technology, 32(2-3): 85-91.

Xia H H, Lin Y S. 2000. Advances of bioremediation of organic-contaminated soil. Pollution Control Technology, 13(1): 46-47.

Yang L P. 2003. On the development of modern petroleum resources in Northwest China. Ph.D.Dissertation. Lanzhou: Northwest Normal University.

Zhang Z Z, Su S M, Luo Y J. 2009. Improvement of natural microbial remediation of petroleum-polluted soil using graminaceous plants. Water Science and Technology, 59: 1025-1035.

Zhu X, Venosa A D, Suidanm T, et al. 2001. Guidelines for the Bioremediation of Marine Shorelines and Freshwaters. Cincinnati: US Environmental Protection Agency. 